\title{
Aerobic deterioration influences the fermentative, microbiological and nutritional quality of maize and sorghum silages on farm in high quality milk and cheese production chains
}

\section{Giorgio Borreani ${ }^{1}$, Thiago Fernandes Bernardes ${ }^{2}$, Ernesto Tabacco ${ }^{1}$}

\author{
${ }^{1}$ Dipartimento di Agronomia, Selvicoltura e Gestione del Territorio, Università di Torino, Grugliasco, Torino, Italy. \\ giorgio.borreani@unito.it \\ ${ }^{2}$ Pós-doutoramento - USP/ESALQ. Bolsista FAPESP
}

RESUMO - As silagens de milho e de sorgo são importantes fontes de energia em rações utilizadas na bovinocultura leiteira, sendo que a estocagem desses volumosos é realizada em silos horizontais com ou sem a presença de paredes laterais (trincheira ou superfície, respectivamente), os quais são atrativos em razão do baixo custo de armazenamento, porém suas conformações determinam grande superfície de exposição, o que torna as silagens mais susceptíveis a deterioração aeróbia. Os maiores problemas envolvendo a qualidade microbiológica e nutricional em silagens, estão relacionados às práticas de manejo na colheita, no abastecimento e compactação da massa, na vedação e, principalmente, durante o desabastecimento do silo. O controle da deterioração aeróbia em silagens pode ser o principal ponto para melhorar a qualidade química, sensorial e higiênica em queijos e no leite fresco. A deterioração aeróbia causa perdas nutricionais e de matéria seca (MS), podendo provocar efeitos indiretos ao animal e ao homens pela transferência de microrganismos patogênicos e micotoxinas ao longo da cadeia alimentar. O presente trabalho tem por objetivo discutir práticas de manejo em fazendas que utilizam silos horizontais no armazenamento de silagem de milho e de sorgo e que produzem leite destinado à fabricação de queijos (tipo pasta dura) que possuem Denominação de Origem Protegida, além de definir aspectos ligados ao manejo na produção de silagens e no controle da deterioração aeróbia das mesmas.

Palavras-chave: deterioração aeróbia, filme plástico, microrganismos espoliadores, Silostop, silagem de milho, práticas de manejo

ABSTRACT: Maize and sorghum silages are good sources of energy for lactating dairy cows that produce milk destined for fresh and matured cheeses. Silages are usually stored in horizontal silos with or without side walls on commercial farms throughout the world. The main microbiological and nutritional quality problems are related to harvesting time, ensiling technology, and management practices during filling and feed-out. Aerobic deterioration is a key point that must avoided on farms in order to improve the hygienic, chemical and sensorial quality of milk and cheeses. Aerobic deterioration causes large losses of dry matter (DM) and quality, and it can cause health problems for animals and humans through the transfer of pathogens and mycotoxins from feed and livestock to food products. The objectives of the present work were to overview management practices connected to the storage of maize and sorghum in horizontal silos on farms producing milk for make Protected Designation of Origin (PDO) hard ripened cheese, to define good management practices that should be applied as the basis for safe silage production and to reduce the extent of aerobic deterioration.

Keywords: aerobic deterioration, management practices, Silostop, plastic film, spoilage microorganisms, maize silage

\section{Introduction}

Silages produced from maize (Zea mais) and Sorghum (Sorghum bicolor) are the main sources of forage of the feed ration for lactating dairy cows in Europe, Northern and Southern America (Wilkinson and Toivonen, 2003). The main principles of forage preservation by ensiling are a rapid achievement of a low $\mathrm{pH}$ through lactic acid fermentation and the maintenance of anaerobic conditions in the completed silo (Woolford, 1990). A large part of the silage stored in horizontal silos (bunkers or piles) is exposed to air and is prone to spoilage, especially in the upper part near the walls which are difficult to seal properly (Ashbell and Lisker, 1988). If the airtight sealing of the silo is not appropriate or during feed out, air penetrates the silage, and oxygen enables various aerobic spoilage microorganisms to become active and to multiply, resulting in aerobic deterioration. Among the different silages, maize is particularly susceptible to aerobic deterioration when it is exposed to oxygen or in the feed bunk (Ashbell and Weinberg, 1992; Kung et al., 1998). 
This is the result of improvements in silage fermentation quality, which preventing butyric acid and minimizing the amount of acetic acid, have increased the risk of aerobically unstable silages (Wyss, 1999; Berger and Bolsen 2006) and this is why well preserved silages are often considered to be more prone to aerobic deterioration than poorly fermented silages (Cai et al., 1999). Aerobic deterioration usually results in high dry matter (DM) loss (Woolford, 1990; Bolsen, 1997) and the loss of important nutritional components (Kung et al., 1998) due to the oxidation of lactic acid and water soluble carbohydrates (WSC), which also leads to reduced preservation quality (Cai et al., 1999; Holzer, et al., 1999). The accumulation of degradation products can affect palatability, cause feed refusal by livestock (Holzer et al., 1999), and produce metabolic disorders in dairy cows (Wilkinson, 1999). Some aerobic microorganisms such as moulds, bacilli, and Listeria monocytogenes, can be harmful to livestock (Ivanek et al., 2006; Driehuis et al., 1999); and further aerobic deterioration can result in the formation of mycotoxins (Borreani et al., 2005; Garon et al., 2006), which can be potentially lethal (Holzer et al., 1999). Aerobic spoilage of silage is associated with the penetration of oxygen into the silage during storage or feeding. All silage exposed to air deteriorates as a result of aerobic microbial activity (Jonsson, 1989). Lactate-assimilating yeasts (Saccharomyces, Candida, Cryptococcus, and Pichia spp.) are usually the initial cause of aerobic deterioration (Pahlow et al., 2003). Some strains of lactate-assimilating yeast grow well in an environment in which the $\mathrm{pH}$ level is between 3 and 8 and the temperature is under $40^{\circ} \mathrm{C}$ (Jonsson, 1989). These conditions are common in maize and sorghum silages when they are first exposed to air. As lactic acid and other residual sugars are combusted and assimilated by yeast, the temperature starts to rise (Jonsson, 1989). Their activity results in an increase in $\mathrm{pH}$, in heat production, and in a loss of DM (Woolford, 1990). Once the temperature is above $45^{\circ} \mathrm{C}$, the amount of yeast present declines and other microbial organisms, such as moulds, bacilli, Listeria, Clostridia, and Enterobacteriaceae, begin to accumulate (Vissers et al., 2007; Lindgren et al., 2002). As aerobic deterioration takes place, there are changes in the chemical parameters of the silage (Lindgren et al., 1985). The $\mathrm{pH}$ level tends to increase, ammonia and amines accumulate, and the levels of organic acids (lactic and acetic acid) tend to decline (Jonsson, 1989). The susceptibility of silage to aerobic deterioration is determined by physical, chemical and microbiological factors such as the DM content at ensiling, the particle size, the filling rate, the pack density in the silo (Johnson et al., 2002), the daily feedout rate (Mahanna and Chase, 2003; Kleinschmit et al. 2005), the type of plastic sealing (Savoie, 1988, Borreani et al., 2007), and the use of silage additives (Muck, 2004) and the fermentation profile (Weinberg and Muck, 1996).

Since silage making is a part of the food chain and silage quality insufficiencies affect animal health, food safety and quality, and environmental pollution, proper management is an important prerequisite.

This overview identifies the main factors related to microbial activity in maize and sorghum silages that affect the extent of aerobic deterioration and losses on commercial farms. The work is also aimed at identifying proper management strategies to improve silage quality and safety in the production chain of typical or Protected Designation of Origin (PDO) cheeses.

\section{Discussion \\ Proper sealing and permeability to oxygen of the sealing cover}

The most important single factor that influences the preservation efficiency of forage ensiling is the degree of anaerobiosis reached in the completed silo (Woolford, 1990). Covering the bunker or drive-over pile shortly after filling the silo is an essential step for proper preservation. However, if the airtight sealing of the silo is not appropriate, air penetrates the silage, and aerobic microorganisms multiply, resulting in aerobic deterioration. Bolsen et al. (1993) reported that DM losses in the top 0.30 to $0.90 \mathrm{~m}$ can exceed $50 \%$ when the silo is not properly covered. Polyethylene film and tyres are the most common method of covering large silos throughout the world. Bolsen (1997) estimated that the value of the lost silage averaged about four times the cost of the plastic and tyres, and labour to apply and remove both.

Berger and Bolsen (2006) summarized the research that documents DM and nutrient losses when bunker silos and drive-over piles of maize and sorghum are not sealed (Table 1). From 1990 to 1993, the top $0.90 \mathrm{~m}$ of silage from 127 bunker silos and piles in 
Kansas was sampled at three locations across the width of the silos. The sampling depths were: 0 to $0.45 \mathrm{~m}$ from the surface (depth 1) and 0.45 to $0.90 \mathrm{~m}$ (depth 2). All the sealed silos were covered with a single sheet of black or white on black, 100 to $150 \mu$ m polyethylene, which was held in place with tyres, sidewall disks, or soil.

In the top $0.45 \mathrm{~m}$, the additional organic matter (OM) losses (losses in addition to the losses in wellpreserved silage) ranged from 7 to $61 \%$, and the losses were higher in bunkers and piles that were not sealed. Applying a seal reduced OM losses in the top $0.45 \mathrm{~m}$ and also reduced additional spoilage losses in the second $0.45 \mathrm{~m}$. The silage near the exposed surface of the unsealed silos had $\mathrm{pH}$ values ranging from 4.75 to 8.55 , which are typical values of severely deteriorated silage. Several of the silages in sealed bunkers and piles had OM losses and $\mathrm{pH}$ values in the top $0.45 \mathrm{~m}$ that were higher than expected, suggesting that the sealing techniques were not effective or the sealing sheets were damaged during the first few months after filling.

Table 1. Effect of crop and sealing treatment on estimated additional spoilage losses of $\mathrm{OM}$ at the top two depths in bunker silos and piles (1990 to 1993 average; from Berger and Bolsen, 2006, modified).

\begin{tabular}{|c|c|c|c|c|c|}
\hline \multirow{2}{*}{$\begin{array}{c}\text { Crop and } \\
\text { treatment }\end{array}$} & \multirow[b]{2}{*}{$\mathrm{n}$ of silos } & \multicolumn{2}{|c|}{$\begin{array}{c}\text { Depth } 1 \\
(0 \text { to } 0.45 \mathrm{~m})\end{array}$} & \multicolumn{2}{|c|}{$\begin{array}{c}\text { Depth } 2 \\
(0.45 \text { to } 0.90 \mathrm{~m})\end{array}$} \\
\hline & & average & range & average & range \\
\hline \multicolumn{6}{|l|}{ MAIZE } \\
\hline sealed & 9 & 23 & $17-31$ & 5.3 & $1-12$ \\
\hline unsealaled & 54 & 50 & $44-60$ & 14.0 & $9-19$ \\
\hline \multicolumn{6}{|l|}{ SORGHUM } \\
\hline sealed & 14 & 21 & $7-27$ & 5.3 & $2-12$ \\
\hline unsealaled & 35 & 44 & $36-61$ & 11.8 & $3-18$ \\
\hline
\end{tabular}

The most common material used to seal bunker silos and drive-over piles is polyethylene film. In the early 1990's, Daponte (1992) proposed the use of coextruded barrier films to seal silage, but, at that time, plastic manufacturers had no commercial interest in these more expensive films. The situation is now rapidly changing and recently new developments in sealing strategies have been reported, involving the use of an improved $45 \mu \mathrm{m}$ thick coextruded film with reduced oxygen permeability, as an alternative to standard polyethylene (Degano, 1999). Studies on the $45 \mu \mathrm{m}$ non-UV stabilized translucent barrier film, in combination with a protective tarpaulin, on maize and grass silages showed both positive (Wilkinson and Rimini, 2002; Berger and Bolsen, 2006) and negligible (O'Kiely and Forristal, 2003; G. Borreani and E. Tabacco, unpublished data) effects on DM losses and visible top surface mould. A new black-on-white (125 $\mu \mathrm{m})$ coextruded oxygen barrier (OB) film has recently been developed for silage sealing by Industria Plastica Monregalese (SILOSTOP, Mondovì, Italy) and has been tested on farm to assess the effects on the fermentation quality, the DM losses and the yeast and mold counts at opening of whole-crop maize bunker silos compared to conventional polyethylene (ST) (Borreani et al., 2007). Two trials were carried out in two commercial farms (Farm 1 and Farm 2). The bunkers were divided into two parts along the length so that half of the feedout face was covered with ST film and the other with OB film (Table 2).

Table 2. Characteristics of the films utilized in the trials on maize bunker silos on farms in Italy (Borreani et al., 2007).

\begin{tabular}{ccc}
\hline & \multicolumn{2}{c}{ Plastic film } \\
\cline { 2 - 3 } Item & $\mathrm{OB}^{1}$ & $\mathrm{ST}$ \\
\hline Thickness, $\mu \mathrm{m}$ & 125 & 180 \\
Specific gravity, g/cm & & 0.937 \\
Weight, g/m & \\
$\begin{array}{c}\text { Oxygen permeability, } \\
\mathrm{cm}^{3} / \mathrm{m}^{2} / 24 \mathrm{~h} \text { at } 1 \text { bar } \\
\text { at } 23^{\circ} \mathrm{C}, 0 \% \mathrm{RH}\end{array}$ & 0.963 & 169 \\
at $23^{\circ} \mathrm{C}, 85 \% \mathrm{RH}$ & 120 & 990 \\
\hline
\end{tabular}

${ }^{1} \mathrm{OB}=$ oxygen barrier film; ST = standard polyethylene film.

The silos were opened for summer consumption and were fed out at different rates (1.30 vs. 2.30 $\mathrm{m} /$ week). The silages were analysed for the DM content, pH, lactic and monocarboxylic acids, ammonia, yeast and mould counts, and aerobic stability (Table 3 ). The $\mathrm{pH}$ of the peripheral silages was different, for Farm 1 and Farm 2 under the two films with lower values in the $\mathrm{OB}$ treatment. The $\mathrm{OB}$ film in Farm 1affected the silage DM losses, which were reduced by 3.7 times in comparison to the ST film sealing. In Farm 2, although the DM losses were numerically higher in the silage sealed with the ST film compared to the OB film (9.0 
vs. $5.9 \%$, respectively), the difference was not statistically significant, However, the maize silage sealed with the ST film was less stable than the silage sealed with the OB film. The results indicate that the new $\mathrm{OB}$ film is a promising tool to constrain spoilage and DM losses in critical farm conditions, when inadequate amounts of silage are removed daily. The OB film further improved the stability of the maize silage in the peripheral area of the silos, even when a proper harvest-to-feedout management was implemented.

Table 3. Fermentation products, DM losses, concentration of moulds and aerobic stability in the peripheral areas of the two silages, sealed with an oxygen barrier (OB) and standard polyethylene (ST) films.

\begin{tabular}{|c|c|c|c|c|}
\hline \multirow[t]{2}{*}{ Item } & \multicolumn{2}{|c|}{ Farm 1} & \multicolumn{2}{|c|}{ Farm 2} \\
\hline & OB & ST & OB & ST \\
\hline $\mathrm{pH}$ & 3.99 & 5.89 & 3.85 & 4.05 \\
\hline $\begin{array}{c}\text { Lactic acid, } \\
\% \text { DM }\end{array}$ & 2.05 & 0.87 & 3.96 & 2.30 \\
\hline $\begin{array}{c}\text { Acetic acid, } \\
\% \text { DM }\end{array}$ & 3.72 & 2.58 & 2.33 & 3.36 \\
\hline $\begin{array}{c}\text { Butyric acid, } \\
\% \text { DM }\end{array}$ & $\begin{array}{c}<0.00 \\
1\end{array}$ & 0.18 & $<0.001$ & $<0.001$ \\
\hline $\begin{array}{c}\mathrm{NH}_{3}-\mathrm{N}, \% \\
\mathrm{TN}\end{array}$ & 10.6 & 11.0 & 6.02 & 7.95 \\
\hline DM losses \% & 10.0 & 37.2 & 5.9 & 9.0 \\
\hline $\begin{array}{l}\text { Moulds, } \\
\log _{10} \mathrm{cfu} / \mathrm{g}\end{array}$ & 1.55 & 5.07 & 1.46 & 1.39 \\
\hline $\begin{array}{c}\text { Aerobic } \\
\text { stability, h }\end{array}$ & 72 & 34 & 355 & 178 \\
\hline
\end{tabular}

\section{Packing density}

Packing silage densely is important for the exclusion of air from the silo to ensure an anaerobic environment where nutrients are preserved. The density of maize and sorghum silages is highly variable in bunker silos. Muck and Holmes (2000) reported values in the range of 125 to $378 \mathrm{~kg} \mathrm{DM} / \mathrm{m}^{3}$ (average $232 \mathrm{~kg}$ $\mathrm{DM} / \mathrm{m}^{3}$ ) for maize silage sampled from 81 commercial bunker silos in Wisconsin. D'Amours and Savoie (2005) reported that the DM density of individual maize silages sampled from six commercial bunker silos ranged from 115 to $361 \mathrm{~kg} \mathrm{DM} / \mathrm{m}^{3}$ (average $234 \mathrm{~kg}$ $\left.\mathrm{DM} / \mathrm{m}^{3}\right)$. A high density is desirable because air infiltration is limited, oxidation loss during storage and feedout is reduced, more DM is stored in the same volume and the fixed costs of storage per unit dry matter are reduced (Johnson et al., 2002). Density is also linked to forage quality and preservation. Ruppel et al. (1995) observed that the loss during storage was inversely proportional to the density. Their model indicated that, over a six-month storage period, dry matter loss decreased from 20 to $10 \%$ when the density increased from 160 to $320 \mathrm{~kg} \mathrm{DM} / \mathrm{m}^{3}$. The recommended minimum pack density of maize and sorghum silages, on a dry basis, is $225 \mathrm{~kg} / \mathrm{m}^{3}$ (Muck and Holmes, 2000). At that level of density, the amount of air that penetrates through the maize silage is minimized; therefore, the growth of detrimental aerobic microorganisms that spoil maize silage is minimized. Harrison et al. (1998) demonstrated that processing maize silage tended to increase wet pack-density most of the time. It was also reported that wet pack density in the silo tended to decline as the maize plant matured (Harrison et al., 1998).

Tabacco and Borreani (2002) reported values in the peripheral areas (top centre and top side, $0.50 \mathrm{~m}$ from the top) of bunker silos and piles of maize silage, observed on 62 commercial farms, to be in the range of 37 to 150 and of 52 to $154 \mathrm{~kg} / \mathrm{m}^{3}$, for bunkers and piles, respectively (Table 4). These data were in the range of values observed by D'Amours and Savoie (2005), who reported that the individual values of density prior to compaction ranged from 42 to $119 \mathrm{~kg} \mathrm{DM} / \mathrm{m}^{3}$ in maize silage placed in buckets of different depths: the average densities were 72,74 , and $76 \mathrm{~kg} \mathrm{DM} / \mathrm{m}^{3}$ for the three depths of $0.15,0.30$, and $0.45 \mathrm{~m}$, respectively. These observations highlight the importance of taking particular care in the packing operations in the last 0.50 $\mathrm{m}$ of the silo. The higher values observed in the peripheral areas were found in farms where silages were maintained below the containing walls of the bunker. Furthermore, it can be observed that the DM density of the core of the surveyed silos was similar with an average value of 195 and $209 \mathrm{~kg} / \mathrm{m}^{3}$, for piles and bunker, respectively.

\section{Silage Removal Rates}

The density and feed-out rate together determine how long a silage can be exposed to air prior to removal from the silo (Muck et al., 2003). If, for example, oxygen is present $1 \mathrm{~m}$ back from the face and 0.10 
$\mathrm{m}$ /day are removed from the silo face, the silage will be exposed to oxygen for ten days prior to leaving the silo, a substantial time for aerobic microorganism to grow and respire digestible components of the silage.

Table 4. DM and bulk densities of maize silages stored in pile or bunker silos (modified from Tabacco and Borreani, 2002).

\begin{tabular}{cccccc}
\hline & & \multicolumn{2}{c}{ DM density $\left(\mathrm{kg} / \mathrm{m}^{3}\right)$} & \multicolumn{2}{c}{ Bulk density $\left(\mathrm{kg} / \mathrm{m}^{3}\right)$} \\
Silo type & Silo zone & average & range & average & range \\
\hline pile & core & 195 & $149-252$ & 578 & $454-699$ \\
& top side & 94 & $52-138$ & 294 & $141-410$ \\
& top centre & 109 & $60-154$ & 318 & $185-428$ \\
bunker & core & 209 & $170-246$ & 593 & $434-713$ \\
& top side & 100 & $37-160$ & 305 & $143-455$ \\
& top centre & 110 & $52-170$ & 333 & $133-487$ \\
\hline
\end{tabular}

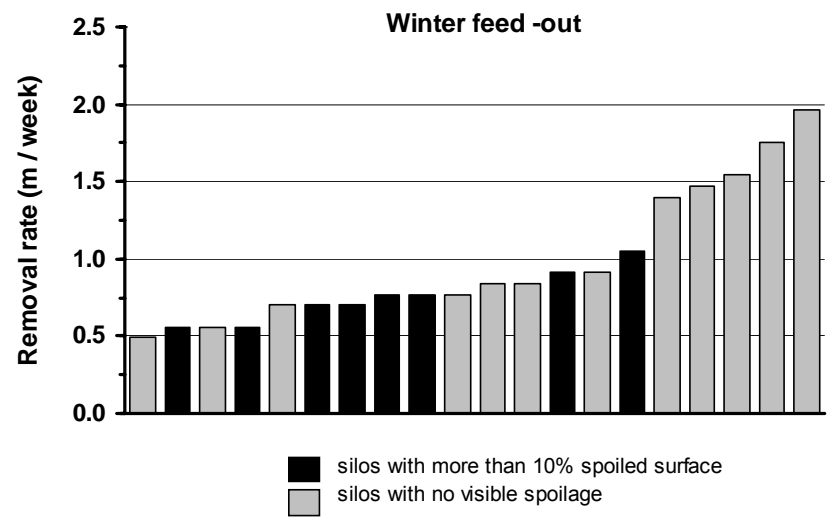

During feed-out, air can penetrate the peripheral areas of a silo to up to $4 \mathrm{~m}$ from the feed-out face, especially when the sealing cover is not weighted down or is only weighted with tyres, suggesting that, in these situations, daily removal rates should be higher than 30 $\mathrm{cm} / \mathrm{d}$ (i.e. $2.10 \mathrm{~m} / \mathrm{week}$ ) to avoid extended aerobic spoilage.

Tabacco and Borreani (2002 and unpublished data), in a survey on commercial farms in Northern Italy (lat. $45^{\circ} \mathrm{N}$ ), observed feed-out rates from $0.5 \mathrm{~m}$ to $1.5 \mathrm{~m} /$ week in more than $70 \%$ of the surveyed farms, with silages subjected to heating and spoiling on more than $10 \%$ of the exposed surface, when the weekly removal rate was lower than 1.0 and 1.5 for winter and summer consumption, respectively (Figure 1).

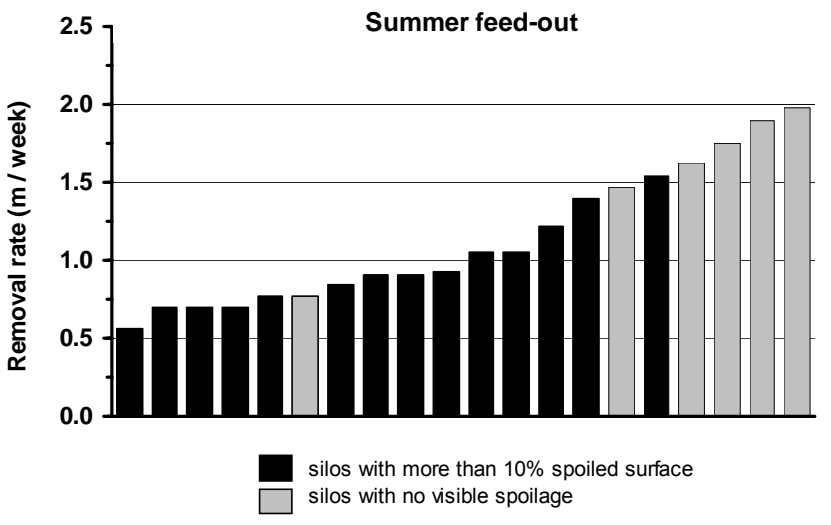

Figure 1. Influence of weekly removal rate on the extent of aerobic deterioration in farm silos during winter and summer consumption (from Tabacco and Borreani, 2002, modified)

Silo face removal rates of 1.10 and $1.50 \mathrm{~m} /$ week are recommended by Pitt and Muck (1993) and by Vissers et al. (2007) for the US and The Netherlands, respectively, to avoid extended aerobic spoilage of the silage. Under warmer conditions, such as in Israel, the recommended bunker silo unloading rates are 1.40 to $2.10 \mathrm{~m} /$ week. An average removal rate 1.35 to 2.10 $\mathrm{m} /$ week from the "face" is a common recommendation in Kansas (Berger and Bolsen, 2006). However, during periods of warm, humid weather, a removal rate of 3.15 $\mathrm{m} /$ week or more might be required to prevent aerobic spoilage, particularly for high-moisture ensiled grains and whole-plant maize, sorghum, and winter cereal silages (Berger and Bolsen, 2006).

\section{Bacterial Inoculants}

Whole-crop cereal silages such as wheat, sorghum and maize are susceptible to aerobic deterioration especially in warm climates. This is because aerobic yeasts are more active at 20 to $30^{\circ} \mathrm{C}$ (Ashbell et al. 2002). Therefore, efforts are being made to find suitable additives that would inhibit fungi and protect silage upon exposure to air. In order to improve the ensiling process, various types of additives have been developed. Biological additives offer certain advantages because they are safe and easy to use, noncorrosive to machinery, do not pollute the environment and are natural products (Filya, 2003). Inoculants could be added to silage in order to stimulate lactic acid fermentation and to accelerate the drop in 
$\mathrm{pH}$. Most available inoculants consist of selected strains of homofermentative LAB strains, such as Lactobacillus plantarum, Enterococcus faecium and Pediococcus species, that can produce great quantities of lactic acid in a short time and therefore stabilize the silage with minimal losses (Weinber et al., 1999). However, these homofermentative LAB strains enhance aerobic deterioration of whole-crop cereal silages, probably because not enough volatile fatty acids are produced to inhibit yeasts and moulds (Weinberg et al. 1993). Muck (1996) was the first to suggest that inoculation with Lactobacillus buchneri, which is an obligate heterolactic acid bacterium, might improve the aerobic stability of silages. Since that time, Lactobacillus buchneri has been used as a silage inoculant to enhance aerobic stability in a variety of silages via the anaerobic degradation of lactic acid to acetic acid. Kleinschmit and Kung (2006) summarized the results of adding Lactobacillus buchneri to silages from 26 experiments on maize and two on sorghum silages. The inoculation treatments were classified in the following categories: 1) untreated silage with nothing applied (LB0), 2) silage treated with L. buchneri at $\leq 1 \times 10^{5} \mathrm{cfu} / \mathrm{g}$ of fresh forage (LB1), and 3) silage treated with L. buchneri at $>1 \times 10^{5} \mathrm{cfu} / \mathrm{g}$ (LB2). In both types of crops, inoculation with $\mathrm{L}$. buchneri decreased the concentrations of lactic acid, and in maize this response was dose-dependent (Table 5). The treatment with $\mathrm{L}$. buchneri markedly increased the concentrations of acetic acid in a dose-dependent manner. The numbers of yeasts were lower in silages treated with LB1 and further decreased in silages treated with LB2, compared to untreated silages. Untreated maize silage spoiled after $25 \mathrm{~h}$ of exposure to air, but maize silage treated with LB1 did not spoil until $35 \mathrm{~h}$, and this stability was further enhanced to $503 \mathrm{~h}$ with LB2. Concerns that high concentrations of acetic acid in silages treated with L. buchneri may depress intake could not be addressed by the meta-analysis because of the reduced number of studies. However, available research has shown that when cattle (Driehuis et al., 1999; Taylor et al., 2002; Kung et al., 2003) and sheep (Ranjit et al., 2002) are fed silages treated with L. buchneri, DM intake is not affected. The recovery of DM after ensiling was lower for LB2 (94.5\%) compared to LB0 and LB1 (95.5\%) in maize silage. Kleinschmit and Kung (2006) concluded their review by stating that the higher rate of inoculation with L. buchneri was more consistently effective in maize silages than in grass and small-grain silages.

Table 5. The effects of Lactobacillus buchneri on chemical and microbiological composition, DM recovery and aerobic stability of maize silages (from Kleinschmit and Kung, 2006, modified)

\begin{tabular}{cccc}
\hline Item & LB0 $^{1}$ & LB1 & LB2 \\
\hline $\mathrm{DM}$ & 30.7 & 30.7 & 30.7 \\
$\mathrm{pH}$ & 3.70 & 3.75 & 3.88 \\
Lactic acid, \% DM & 6.59 & 5.87 & 4.79 \\
Acetic acid, \% DM & 2.18 & 2.63 & 3.89 \\
Propionic acid, \% DM & 0.08 & 0.06 & 0.11 \\
DM losses \% & 4.5 & 4.5 & 5.5 \\
Yeasts, $\log _{10} \mathrm{cfu} / \mathrm{g}$ & 4.18 & 3.10 & 1.88 \\
Aerobic stability, h & 25 & 35 & 503 \\
\hline
\end{tabular}

${ }^{1}$ untreated silage with nothing applied (LB0); silage treated with L. buchneri at $\leq 1 \times 10^{5} \mathrm{cfu} / \mathrm{g}$ of fresh forage (LB1); silage treated with L. buchneri at $>1 \times 10^{5} \mathrm{cfu} / \mathrm{g}$ (LB2)

In order to use biological additives to overcome the problem of the aerobic deterioration of silages, it has been suggested that other types of inoculants, such as Bacillus species and propionic acid bacteria (PAB) should be used (Pahlow and Honig 1994). It could be expected that such additives would produce substances in the silage, with antimycotic properties and which would, therefore, inhibit the development of yeasts and moulds upon aerobic exposure. PAB can ferment sugars and lactate to acetate and propionate; these short-chain aliphatic acids inhibit all yeasts and moulds (Moon 1983). Weinberg et al. (1995a,b), Higginbotham et al. (1998), and Filya et al. (2006) showed that the addition of a PAB inoculant only led to a small improvement or no appreciable effect on the aerobic stability of wheat, sorghum and maize silages.

\section{Implication of silage quality on milk quality and on cheese making}

The conditions associated with well preserved silage, i.e. low $\mathrm{pH}$ and anaerobiosis, are also unfavourable for the growth of most moulds. However, if air gains access, silage is at risk from storage moulds, especially in the peripheral areas, through leakages in the plastic films or at opening for feeding-out. Spoilage 
of silages by filamentous fungi involves nutrient and energy losses and the risk of contamination by mycotoxins (Wilkinson, 1999). Mycotoxin contamination in maize grain has been widely described, while limited information is available about mycotoxins in maize silage (Oldenburg, 1991). Identifying the conditions for mycotoxin production in relation to silage conservation techniques could help in the development of strategies to restrict toxin and mould contamination and allow effective management of the problem. Cavallarin et al. (2004) presented the results of a survey for mycotoxin contamination on farm maize forages and silages and discussed the relationship between mycotoxin presence and the level of aerobic deterioration. The survey was carried out over two years in the Po Plain in Italy on 20 dairy farms. 96 samples of maize forage at ensiling were taken, and the resulting 50 clamp silos (25 for winter feeding and 25 for summer feeding) and 23 piles (16 for winter feeding and 7 for summer feeding) were sampled both in the central (C) and in the peripheral (T) areas. The mycotoxin contamination is reported in Table 6 . As far as zearalenone (ZEA) is concerned, a high variability in contamination was observed in silages, according to the different zones of the silo, with the highest values corresponding to the top areas. A contamination higher than $300 \mathrm{ppb}$ was found in $13 \%$ of the cases, which represents the maximum recommended value for feed. Figure 2 shows the working face of a silo opened in summer, with highly aerobically deteriorated peripheral areas. In these zones the ZEA values were up to 40 times higher than those of forage at ensiling, while in non deteriorated areas, the ZEA concentration was similar to that of the corresponding forage at ensiling. Aflatoxin $\mathrm{B}_{1}\left(\mathrm{AFB}_{1}\right)$ showed higher average values in silages in comparison to forages at ensiling. The $17 \%$ of silage samples showed higher values than $4 \mathrm{ppb}$, which could determine a risk of contamination of milk by aflatoxin $M_{1}$ in high producing dairy cows with a daily intake of $25 \mathrm{~kg}$ silage FM cow $^{-1}$ day ${ }^{-1}$ (Veldman et al., 1992). The International Agency for Research on Cancer of WHO (IARC, 2002) includes aflatoxins among the substances that are carcinogenic for humans (Group 1). The European Community has established that maximum levels of $\mathrm{AFM}_{1}$ in milk should not exceed $50 \mathrm{ppt}$ (European Commission, 2001), in order to prevent higher concentrations than $500 \mathrm{ppt}$ when milk is processed to cheese.

Table 6. Occurrence of zearalenone and aflatoxin B1 in maize forage and silage. For each mycotoxin, the values are expressed as a percentage of the total number of samples $(n=186)$

\begin{tabular}{lcccc}
\hline Zearalenone & & ND $^{\mathrm{A}}$ & $30-300 \mathrm{ppb}$ & $>300 \mathrm{ppb}$ \\
\hline & Forage & 48 & 50 & 2 \\
& Silage zone $\mathrm{C}^{\mathrm{B}}$ & 40 & 55 & 5 \\
& ${\text { Silage zone } \mathrm{T}^{\mathrm{C}}}$ & 40 & 47 & 13 \\
\hline Aflatoxin $\mathrm{B}_{1}$ & & $\mathrm{ND}$ & $0.6-4.0 \mathrm{ppb}$ & $>4.0 \mathrm{ppb}$ \\
\hline & Forage & 21 & 79 & 0 \\
& Silage zone C & 9 & 83 & 9 \\
& Silage zone $\mathrm{T}$ & 5 & 87 & 8 \\
\hline
\end{tabular}

${ }^{A} \mathrm{ND}=$ under detection limit; ${ }^{\mathrm{B}} \mathrm{C}=$ central; ${ }^{\mathrm{C}} \mathrm{T}=$ top

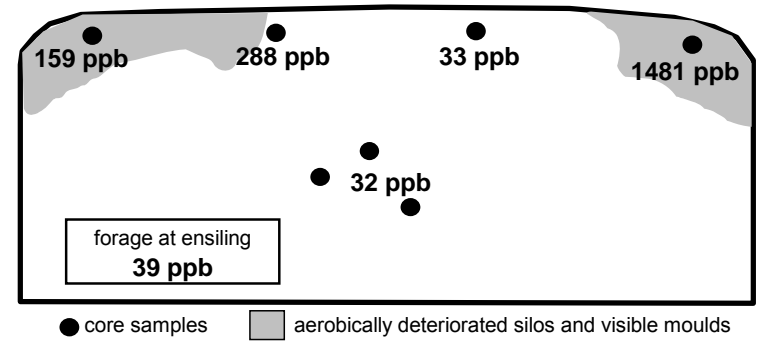

Figure 1. Example of a summer silo with top-side aerobically deteriorated zones and zearalenone contamination.

Hoffman and Ocker (1997) fed aerobically stable and unstable high moisture shelled maize to midlactation cows for three, 14-day periods. The milk yield of the cows fed the aerobically deteriorated maize declined by approximately $3.2 \mathrm{~kg}$ per cow per day during each period compared to cows fed fresh, aerobically stable high moisture maize. Bolsen et al. (2002) clearly indicated that feeding surface spoilage had greater negative impacts on the nutritive value of maize silage-based diets, with a reduction of the intake of steers from 8 to $6.7 \mathrm{~kg}$ per head per day.

Recently, Vissers et al. (2006, 2007) have emphasized the role of aerobic deterioration on maize silage at a farm level in relation to the presence of high concentrations of Clostridium and Bacillus spores in tank milk. The ability of these genus to form endospores is the reason for their continuing, undesirable presence later on in the food production system (Lindgren et al., 2002; Te Giffel et al., 1995). 
The spore-forming properties generally allows the organism to survive for long periods under unfavorable environmental conditions. The growth of clostridia in silage can take place during the acidification phase, the storage phase, and upon exposure of the material to air, as demonstrated by Jonsson (1991). When silage is exposed to air, the oxygen penetrates deep into it, and aciduric aerobic organisms (e.g., yeast) consume oxygen and, at the same time, the substances that inhibit the clostridia growth, i.e., organic acids produced by anaerobic fermentation. The consumption of both acids and oxygen leads to the development of micro-niches with less inhibitory activity, which might allow the growth of clostridia (Jonsson, 1989). Clostridial spores from highly contaminated silages may pass into the milk (Stadhouders and Spoelstra, 1990) via dung contamination, even if good hygienic milking conditions are practiced (Stadhouders and Jørgensen, 1990). Clostridia spores survive milk pasteurization and pass unaffected into cheese. Due to their ability to ferment lactate, Clostridium tyrobutyricum and Clostridium butyricum can multiply in many types of hard and semihard cheeses (Grana, Tilsit, ParmigianoReggiano, Emmenthal, Gruyère, Gouda, Edam, etc.) and result in a defect called 'late blowing,' due to the abnormal gas production $\left(\mathrm{H}_{2}\right.$ and $\left.\mathrm{CO}_{2}\right)$ which accompanies butyric acid production.

\section{Conclusion}

Silage spoilage and microbial proliferation could have negative consequences and great economic impacts on feed and food quality, on animal production and on animal and human welfare. The quality of silages as livestock feed and their potential impact on human health begins with the growing and continues with the harvest, and safe conservation of feedstuffs in the farmers' silos. Optimizing management practices and improving farm storage techniques that reduce aerobic deterioration of silages could help to improve the safety of the entire production chain, especially when milk is destined for the production of high quality cheeses. Nowadays, most farmers have the skills, the knowledge and the means of making good silages to produce high quality and safe dairy products.

\section{References}

ASHBELL, G.; LISKER, N. Aerobic deterioration in maize silage stored in a bunker silos under farm conditions in a subtropical climate. Journal of the Science of Food and Agriculture, v. 45, p. 307-315, 1988.

ASHBELL, G.; WEINBERG, Z.G. Top silage losses in horizontal silos. Canadian Agricultural Engineering, v. 34, p. 171-175, 1992 .

ASHBELL, G.; WEINBERG, Z.G.; HEN, Y.; FILYA, I. The effects of temperature on the aerobic stability of wheat and corn silages. Journal of Industrial Microbiology and Biotechnology, v. 28, p. 261-263, 2002.

BERGER, L.L.; BOLSEN, K.K. Sealing strategies for bunker silos and drive-over piles. In: Proc. Silage for Dairy Farms: Growing, Harvesting, Storing, and Feeding. NRAES Publ. 181. Ithaca, NY, 2006.

BOLSEN, K.K. Issues of top spoilage losses in horizontal silos. In: Proceedings of Silage: Field to Feedbunk. NRAES Publ. 99. Ithaca, NY. p. 137-150, 1997.

BOLSEN, K.K.; DICKERSON, J.T.; BRENT, B.E.; SONON Jr. R.N.; DALKE, B.S.; LIN, C.; BOYER, Jr. J.E. Rate and extent of top spoilage losses in horizontal silos. Journal of Dairy Science, v. 76, p. 2940-2962, 1993.

BOLSEN, K.K.; WHITLOCK, L.A.; URIARTE-ARCHUNDIA, M.E. Effect of surface spoilage on the nutritive value of maize silage diets. Proc. XIII International Silage Conference. Auchinruive, Scotland p. 76-77, 2002.

BORREANI, G.; TABACCO, E.; ANTONIAZZI, S.; CAVALLARIN L. Zearalenone contamination in farm maize silage. Italian Journal Animal Science, v. 4, p. 162$165,2005$.

BORREANI, G.; TABACCO, E.; CAVALLARIN, L. A new oxygen barrier film reduces aerobic deterioration in farmscale corn silage. Journal of Dairy Science, v. 90, p. 47014706, 2007.

CAI, Y.; BENNO, Y.; OGAWA, M.; KUMA, S. Effect of applying lactic acid bacteria isolated from forage crops on fermentation characteristics and aerobic deterioration of silage. Journal of Dairy Science, v. 82, p. 520-526, 1999.

CAVALLARIN, L., BORREANI, G.; TABACCO, E. Mycotoxin occurrence in farm maize silages in northern Italy. Proc. 20th General Meeting of the European Grassland Federation, 21-24 June 2004, Luzern, Switzerland, v. 9, p. 1023-1025, 2004.

D'AMOURS, L.; SAVOIE, P. Density profile of corn silage in bunker silos. Canadian Biosystems Engineering, v. 47, p. 2.21-2.28, 2005.

DAPONTE, T. Coextruded films in silage. Plasticulture, v. 96 (4), p. 35-44, 1992.

DEGANO, L. Improvement of silage quality by innovative covering system. In Proc. 12th Int. Silage Conf., Uppsala, Sweden. British Grassland Society, Reading, UK, p. 296297, 1999.

DRIEHUIS, F.; OUDE ELFERINK, S.J.W.H.; VAN WIKLEAAR, P.G. Lactobacillus buchneri improves the aerobic stability of laboratory and farm scale whole crop maize but does not affect feed intake and milk production of dairy cows. In Proc. 12th Intl. Silage Conf., Uppsala, Sweden. Swedish Univ. Agric. Sci., Uppsala, p. 106-107, 1999. 
EUROPEAN COMMISSION. 2001. Commission Regulation 2001/466/EC of 8 March 2001 setting maximum levels for certain contaminants in foodstuffs (Text with EEA relevance). Official Journal European Community, L. v. 77, p. 1-13.

FILYA, I. The effect of Lactobacillus buchneri and Lactobacillus plantarum on the fermentation, aerobic stability, and ruminal degradability of low dry matter corn and sorghum silages. Journal of Dairy Science, v. 86, p. 3575-3581, 2003.

FILYA, I; SUCU, E; KARABULUT, A. The effects of Propionibacterium acidipropionici and Lactobacillus plantarum, applied at ensiling, on the fermentation and aerobic stability of low dry matter corn and sorghum silages. Journal of Industrial Microbiology and Biotechnology, v. 33, p. 353-358, 2006.

GARON, D.; RICHARD, E.; SAGE, L.; BOUCHART, V.; POTTIER, D.; LEBAILLY, P. Mycoflora and multimycotoxin detection in corn silage: experimental study. Journal of Agricultural and Food Chemistry, 54:3479-3484, 2006

HARRISON, J.H.; JOHNSON, L.; DAVIDSON, D.; HUOT, D.; HORN, M.; MORGAN, L.; SHINNERS, K.; LINDER, D.; ROTZ, A.; MUCK, R.; MAHANNA, B. Effect of maturity, chop length, mechanical processing, and silo type on packed density of corn silage. Journal of Dairy Science, v. 81(Suppl. 1) p. 199, 1998.

HIGGINBOTHAM, G.E., MUELLER, S.C.; BOLSEN, K.K.; DEPETERS, E.J. Effects of inoculants containing propionic acid bacteria on fermentation and aerobic stability of corn silage. Journal of Dairy Science, v. 81, p. 2185-2192, 1998.

HOFFMAN, P.C.; OCKER, S.M. Quantification of milk yield losses associated with feeding aerobically unstable high moisture corn. Journal of Dairy Science, v. 80(Suppl.1), p. 234, 1997.

HOLZER, M.; MAYRHUBER, E.; DANNER, H.; MADZINGAIDZO, L.; BRAUN, R. Effect of Lactobacillus sp. and Enterococcus sp. on silaging and aerobic stability. Proc. XII International Silage Conference. Uppsala, Sweden. p. 270-271, 1999.

IARC. Some traditional herbal medicines, some mycotoxins, naphthalene and styrene. Summary of data reported and evaluation. IARC Monographs on the Evaluation of the Carcinogenic Risk to Humans. International Agency for Research on Cancer, Lyon, France, v. 82. 2002.

IVANEK, R.; GRÖHN, Y.; WIEDMANN, M. Listeria monocytogenes in multiple habitats and host populations: review of available data for mathematical modeling. Foodborne Pathogen and Disease, v. 3, p. 319-336, 2006.

JOHNSON, L.M.; HARRISON, J.H.; DAVIDSON, D.; MAHANNA, W.C.; SHINNERS, K.; LINDER, D. Corn silage management: Effects of maturity, inoculation, and mechanical processing on pack density and aerobic stability. Journal of Dairy Science, v. 85, p. 434-444, 2002.

JONSSON, A. The role of yeasts and clostridia in silage deterioration. Ph.D. Diss. Swedish University of Agricultural Sciences, Uppsala, Sweden, 1989.

JONSSON, A. Growth of Clostridium tyrobutyricum during fermentation and aerobic deterioration of grass silage. Journal of the Science of Food and Agriculture, v. 54, p. $557-568,1991$.

KLEINSCHMIT, D.H.; KUNG Jr., L. A meta-analysis of the effects of Lactobacillus buchneri on the fermentation and aerobic stability of corn and grass and small-grain silages. Journal of Dairy Science, v. 89, p. 4005-4013, 2006.
KLEINSCHMIT, D.H.; SCHMIDT, R.J.; KUNG Jr., L. The effects of various antifungal additives on the fermentation and aerobic stability of corn silage. Journal of Dairy Science, v. 88, p. 2130-2139, 2005.

KUNG, L. Jr., SHEPERD, A.C.; SMAGALA, A.M.; ENDRES, K.M.; BESSETT, C.A.; RANJIT, N.K.; GLANCEY, J.L. The effect of preservatives based on propionic acid on the fermentation and aerobic stability of corn silage and a total mixed ration. Journal of Dairy Science, v. 81, p. 13221330, 1998.

KUNG, L., Jr.; TAYLOR, C.C.; LYNCH, M.P.; NEYLON, J.M. The effect of treating alfalfa with Lactobacillus buchneri 40788 on silage fermentation, aerobic stability, and nutritive value for lactating dairy cows. Journal of Dairy Science, v. 86, p. 336-343, 2003.

LINDGREN, S.; PETTERSSON, K.; KASPERSSON, A.; JONSSON, A.; LINGVALL, P. Microbial dynamics during aerobic deterioration of silages. Journal of the Science of Food and Agriculture, v. 36, p. 765-774, 1985.

LINDGREN, S.; OLDENBURG, E.; PAHLOW, G. Influences of microbes and their metabolites on feed and food quality. In K. Segaard et al. (ed.) Proc. 18th General Meeting of the European Grassland Federation, Aalborg, Denmark. 22-25 May 2000. British Grassland Society, Reading, UK, p. 503-511, 2002.

MAHANNA, B.; CHASE, L.E. Practical applications and solutions to silage problems. In Silage Science and Technology. D. R. Buxton, R. E. Muck, and J. H. Harrison (eds). ASA, CSSA, SSSA, Madison, WI, v. 42, p. 855-895 2003.

MOON, N.J. Inhibition of the growth of acid-tolerant yeasts by acetate, lactate, and propionate and their synergistic mixtures. Journal of Applied Bacteriology, v. 55, 453-460, 1983.

MUCK, R.E. A lactic acid bacteria strain to improve aerobic stability of silages. In U.S. Dairy Forage Research Center 1996 Research Summaries. Madison, WI, p. 42-43, 1996.

MUCK, R.E. Effects of corn silage inoculants on aerobic stability. Transactions of the ASAE, v. 47, p. 1011-1016, 2004.

MUCK, R.E.; HOLMES, B.J.; Factors affecting bunker silo densities. Applied Engineering in Agriculture, v. 16(6), p. 613-619, 2000.

MUCK, R.E.; MOSER, I.E.; PITT, R.E. Postharvest factors affecting ensiling. In Silage Science and Technology. D. R. Buxton, R. E. Muck, and J. H. Harrison (eds). ASA, CSSA, SSSA, Madison, WI, v. 42, p. 251-304, 2003.

OLDENBURG, E. Mycotoxins in conserved forage. In: G. Pahlow, H. Honig (eds). Proc. Conf., Forage Conservation towards 2000, Landbauforshung Völkenrode, Sonderheft, v. 123 , p. $191-205,1991$

O'KIELY, P.; FORRISTAL, P.D. An alternative plastic film for sealing ensiled forage. In Proc. Agric. Res. Forum, Tullamore, 3-4 March, p. 27, 2003.

PAHLOW, G.; HONIG, H. The role of microbial additives in the aerobic stability of silage. In Workshop Proc. 15th General Mtg. Eur. Grassl. Fed., Wageningen, The Netherlands. Eur. Grassl. Fed., Wageningen, The Netherlands, p. 149-151, 1994.

PAHLOW, G.; MUCK, R.E.; DRIEHUIS, F.; OUDE ELFERINK, S.J.W.H.; SPOELSTRA, S.F. Microbiology of ensiling. In Silage Science and Technology. D. R. Buxton, R. E. Muck, and J. H. Harrison (eds). ASA, CSSA, SSSA, Madison, WI, v. 42, p. 31-93, 2003. 
PITT, R.E., MUCK, R.E. A diffusion model of aerobic deterioration at the exposed face of bunker silos. Journal of Agricultural Engineering Research, v. 55, p. 11-26, 1993.

RANJIT, N.K.; TAYLOR, C.C.; KUNG, L. Jr. Effect of Lactobacillus buchneri 40788 on the fermentation, aerobic stability and nutritive value of maize silage. Grass and Forage Science, v. 57, p. 73-81, 2002.

RUPPEL, K.A.; PITT, R.E.; CHASE, L.E.; GALTON, D.M.; Bunker silo management and its relationship to forage preservation on dairy farms. Journal of Dairy Science, v. 78, p. 141-153, 1995.

SAVOIE, P. Optimization of plastic covers for stack silos. Journal of Agricultural Engineering Research, v. 41, p. 6573, 1988

STADHOUSERS, J.; JØRGENSEN, K. Prevention of the contamination of raw milk by a hygienic milk production. Bulletin of the International Dairy Federation, v. 251, p. 32-36, 1990.

STADHOUSERS, J.; SPOELSTRA, S.F. Prevention of the contamination of raw milk by making a good silage. Bulletin of the International Dairy Federation, v. 251, p. 2431, 1990.

TABACCO, E.; BORREANI, G. Contrastare il deterioramento aerobico negli insilati di mais. L'Informatore Agrario, v. 58 (15), p. 105-111, 2002.

TAYLOR, C.C.; RANJIT, N.J.; MILLS, J.A.; NEYLON, J.M.; KUNG, L. Jr. The effect of treating whole-plant barley with Lactobacillus buchneri 40788 on silage fermentation, aerobic stability, and nutritive value for dairy cows. Journal of Dairy Science, v. 85, p. 1793-1800, 2002.

TE GIFFEL, M.C.; BEUMER, R.R.; SLAGHUIS, B.A.; ROMBOUTS, F.M. Occurrence and characterization of (psychrotrophic) Bacillus cereus on farms in the Netherlands. Netherlands Milk and Dairy Journal, v. 49, p. 125-138, 1995.

VELDMAN, A.; MEIJS, J.A.C.; BORGGREVE, G.J.; HEERESVAN DER TOL, J.J. Carry-over of aflatoxin from cows' food to milk. Animal Production, v. 55, p. 163-168, 1992.

VISSERS, M.M.M.; DRIEHUIS, F.; TE GIFFEL, M.C.; DE JONG, P.; LANKVELD, J.M.G. Minimizing the level of butyric acid bacteria spores in farm tank milk. Journal of Dairy Science, v. 90, p. 3278-3285, 2006.
VISSERS, M.M.M.; DRIEHUIS, F.; TE GIFFEL, M.C.; DE JONG, P.; LANKVELD, J.M.G. Concentrations of butyric acid bacteria spores in silage and relationships with aerobic deterioration. Journal of Dairy Science, v. 90, p. 928-936, 2007.

WEINBERG, Z.G.; ASHBELL, G.; HEN, Y.; AZRIELI, A. The effect of applying lactic acid bacteria at ensiling on the aerobic stability of silages. Journal of Applied Bacteriology, v. 75, p. 512-518, 1993.

WEINBERG, Z.G.; ASHBELL, G.; BOLSEN, K.K.; PAHLOW, G.; HEN, Y.; AZRIELI, A. The effect of a propionic acid bacterial inoculant applied at ensiling, with or without lactic acid bacteria, on the aerobic stability of pearl millet and maize silages. Journal of Applied Bacteriology, v. 78, p. 430-436, 1995a.

WEINBERG, Z.G.; ASHBELL, G.; HEN, Y.; AZRIELI, A. The effect of propionic acid bacterial inoculant applied at ensiling on the aerobic stability of wheat and sorghum silages. Journal of Industrial Microbiology, v. 15, p. $493-$ 497, 1995b.

WEINBERG, Z.G.; MUCK, R.E. New trends and opportunities in the development and use of inoculants for silage. FEMS Microbiology Reviews, v. 19, p. 53-68, 1996.

WEINBERG, Z.G.; SZAKACS, G.; ASHBELL, G.; HEN, Y. The effect of Lactobacillus buchneri and L. plantarum, applied at ensiling, on the ensiling fermentation and aerobic stability of wheat and sorghum silages. Journal of Industrial Microbiology Biotechnology, v. 23, p. 218-222, 1999.

WILKINSON, J.M. Silage and animal health. Natural Toxins, v. 7, p. 221-232, 1999.

WILKINSON, J.M.; RIMINI, R. Effect of triple co-extruded film (TCF) on losses during the ensilage of ryegrass. In Proc. 13th Int. Silage Conf., Auchincruive, Scotland, British Grassland Society, Reading, UK, p. 168-169,2002.

WILKINSON, J.M.; TOIVONEN, M.I. World Silage, Chalcombe Publications, p. 105-111, 2003.

WYSS, U. Influence of pre-wilting degree on aerobic stability of grass silages. Proc. XII International Silage Conference. Uppsala, Sweden, p. 284-285, 1999.

WOOLFORD, M.K. The detrimental effect of air on silage. Journal of Applied Bacteriology, v. 68, p. 101-116, 1990. 